\title{
開口部と開放部を有する中低層建築物の津波水槽実験 \\ TSUNAMI WATER TANK EXPERIMENT ON LOW-TO-MID-RISE BUILDINGS WITH OPENINGS AND PILOTI SPACE
}

\author{
濱本卓 司*1, 鴫原良典*2, 矢代晴 実*3, 井上修作*4 \\ Takuji HAMAMOTO, Yoshinori SHIGIHARA, Harumi YASHIRO \\ and Shusaku INOUE
}

\begin{abstract}
A series of tsunami water tank experiments have been conducted to study global and local tsunami actions on low-to-mid-rise buildings with or without openings and piloti space. Each small-scaled experimental model produced by 3D printer is assumed as a three-story building of square plan with four corner columns and a center core. Wave pressures generated on several portions of external and internal walls are measured to discuss the local tsunami action, whereas wave forces acting on the whole building are measured to discuss the global tsunami action. Numerical analyses have been carried out to simulate the flow of tsunami inside and outside of the buildings and its effect on building structures through the comparison with experimental results.
\end{abstract}

Keywords: Tsunami water tank experiment, Tsunami-resistant design, Survivability, Openings, Piloti space, Tsunami simulation analysis 津波水槽実験，対津波設計，残存性能，開口部，開放部，津波シミュレーション解析

\section{1. 序}

津波に対する残存性能は，沿岸域に建つ建築物にとって，人命保護 と機能維持の観点から基本的な要求性能である。東日本大震災では, 津波により多くの建築物が倒壊し流失する中で，ガラス空や扉の破壊 による開口部の形成や外装材の流出による開放部の形成（ピロティ化） により結果的に流体力が低減されて残存した事例が散見された 1)。こ のような状況は，残存性能を建築物に付与寸る設計法として，津波に 耐える「耐津波設計」だけでなく，津波を受け流す「対津波設計」を 考えることの有効性を示唆している 2)

建築物の「対津波設計」の確立のためには，今後，三次元形状によ る建物外部に作用する波力の違い，建物内部に浸入した津波が内壁等 に作用する付加的な外力の影響，浮力や揚力による鉛直力の発生，津 波の建物内滞留による内圧の増大，押し波と引き波の繰り返し作用の 影響など, 土木構造物には見られない建築物特有の問題に関して定量 的な検討を蓄積していく必要がある。

開放部や開口部の存在が建築物外部に作用寸る水平荷重に与える 影響については，すでに国土交通省の告示 3), 4)や日本建築学会の建築 物荷重指針 5), 6)に示されている。しかし，現時点では土木工学で蓄積 された津波荷重に関する知見を建築物にそのまま適用した段階に留 まっており，上述した建築物特有の問題に関する本格的な検討はまだ 始まったばかりといえる。

本研究は，東日本大震災後，巨大津波に対して建築分野における独
自の検討の必要性を指摘した日本建築学会の東日本大震災第二次提 言 7)受けて実施した津波水槽実験に基づく基礎的研究である。ピロ ティの有無と開口部の有無を組み合わせた 3 タイプの 3 層建物模型を 製作し，建物内部に浸入した津波の流況，構造材や非構造材に作用寸 る局所的な波圧分布，浮力や揚力による鉛直力の影響などに関して検 討する。さらに, 実験の状況を再現した津波シミュレーション解析を 行い，実験結果との比較検討を通して開口部と開放部(ピロティ)を有 する中低層建築物の津波作用時における力学的メカニズムについて 考察する。

\section{2. 実験内容}

\section{1 建物模型}

対象建物として正方形平面の $\mathrm{RC}$ 造 3 階建てオフィスビルを想定し た. 建物模型は縮尺 $1 / 80$ とし, 四隅に柱を配し, 中央部にコアを設 けた。ピロティなしとピロティありの建物模型の 1 階平面と立面を Fig. 1 に示す。ピロティありは，ピロティなしから 1 階の腰壁と垂れ 壁を除去した状態であり，コアは残している。平面寸法は $150 \mathrm{~mm} \times 150 \mathrm{~mm}$ ，階高は $50 \mathrm{~mm}$ ，柱断面は $20 \mathrm{~mm} \times 20 \mathrm{~mm}$ ，壁厚は $5 \mathrm{~mm}$ とし, 各階に壁高 $15 \mathrm{~mm}$ の腰壁と壁高 $10 \mathrm{~mm}$ の垂れ壁を付け, 各階 4 面の開口部は $110 \mathrm{~mm} \times 25 \mathrm{~mm}$ とした。コアは $50 \mathrm{~mm} \times 30 \mathrm{~mm}$ で 壁厚 $4 \mathrm{~mm}$ のボックス壁とし，内部は波圧計の配線スペースに利用し た。ゴム製パッキングを介して波圧計を埋め込むために, 各階の腰壁
*1 東京都市大学 名誉教授. 丁博

*2 防衛大学校 講師・博士 (工学)

*3 防衛大学校 教授・博士 (工学)

*4 竹中工務店技術研究所 博士 (工学)
Emeritus Prof., Tokyo City University, Dr.Eng.

Lect., National Defense Academy, Dr.Eng.

Prof., National Defense Academy, Dr.Eng.

Takenaka Corporation, Dr.Eng. 

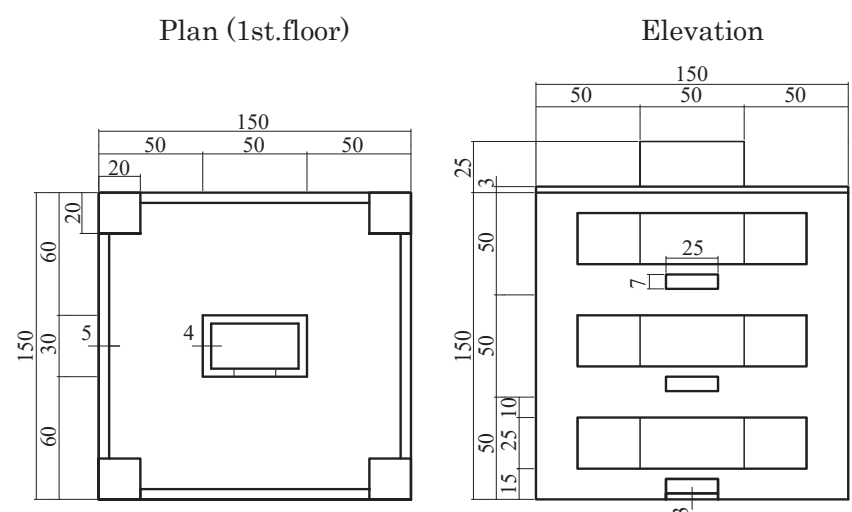

Without piloti space

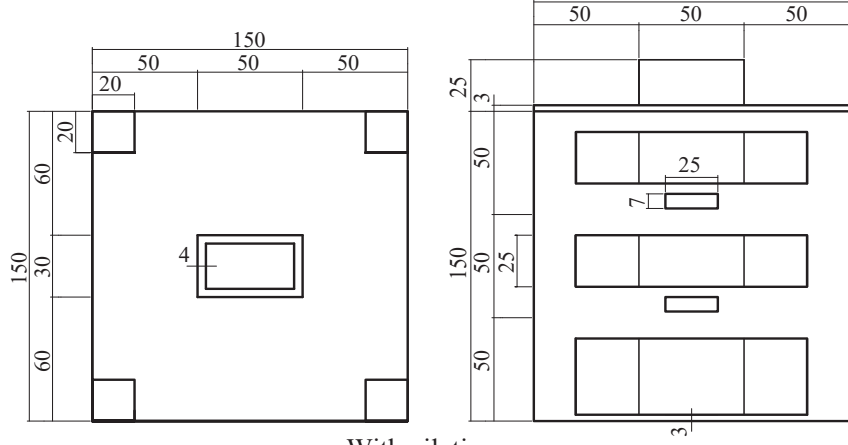

With piloti space

Fig. 1 Experimental building model (Unit: mm)

とコアの下部中央に $25 \mathrm{~mm} \times 7 \mathrm{~mm}$ の小さな開口を設けた。

ピロティなし・開口部あり，ピロティあり・開口部あり，およびピ ロティなし・開口部なし（波力測定のみ）の 3 タイプの模型を $3 \mathrm{D}$ プ リンターにより製作した。模型の素材にはプラスチックを用いた。ピ ロティなし・開口部なしの模型は，すべての構面を無開口壁とした立 方体 $150 \mathrm{~mm} \times 150 \mathrm{~mm} \times 150 \mathrm{~mm}$ の屋上にペント八ウスが載る形状であ る。このピロティなし・開口部なしに対して，ピロティなし・開口部 ありの開口率は $37 \%$ ，ピロティあり・開口部ありの開口率は $44 \%$ とな った。開口部に関しては, ガラス空なしとガラス空ありの状態に分け て実験を行った。ガラス空なしの模型を Photo 1 に, ガラス空ありの 模型を Photo 2 に示す。ガラス空なしは，ガラス空を取り付けずに完 全開口とした。ガラス空ありは，開口部にゴム製の空枠を取り付け， 枠内に一つずつ透明なプラスチック製のガラス空をはめ込み，波圧が 作用すると外れて流失するようにした。

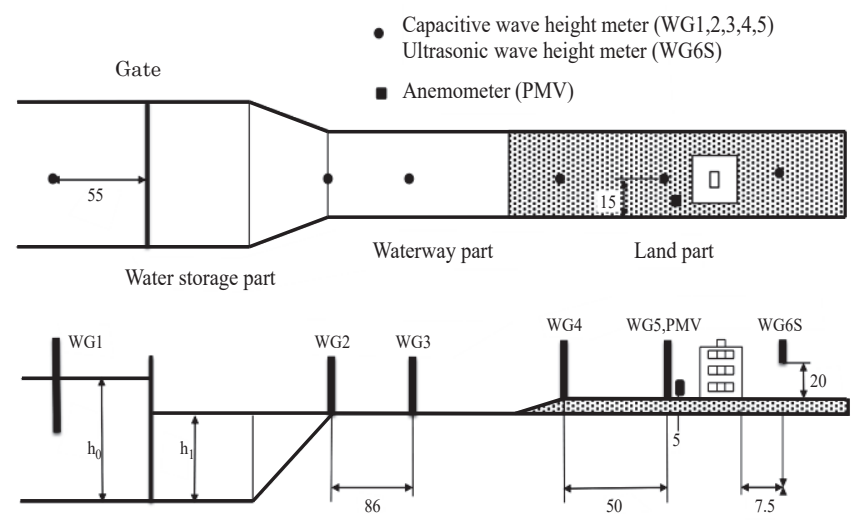

Fig. 2 Tsunami-making water tank and measuring devices (Unit: cm)

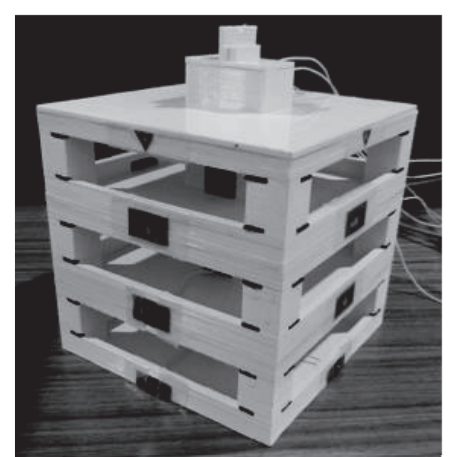

Without piloti space

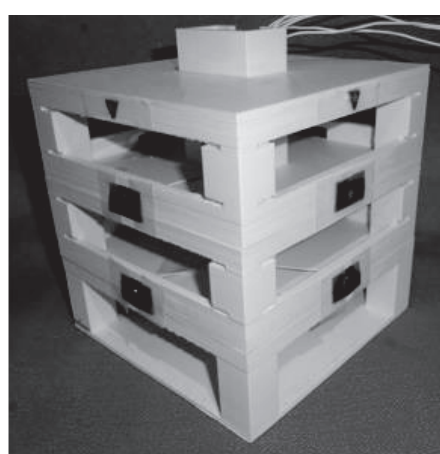

With piloti space
Photo 1 Experimental building model without glass windows

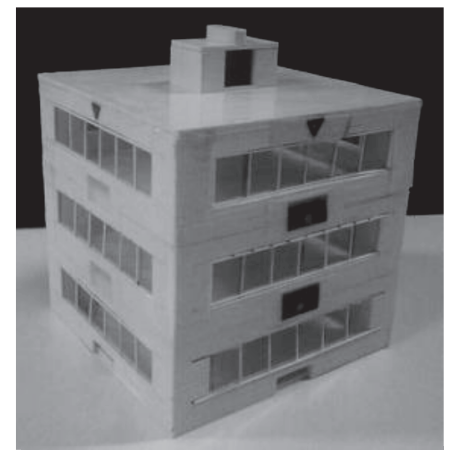

Without piloti space

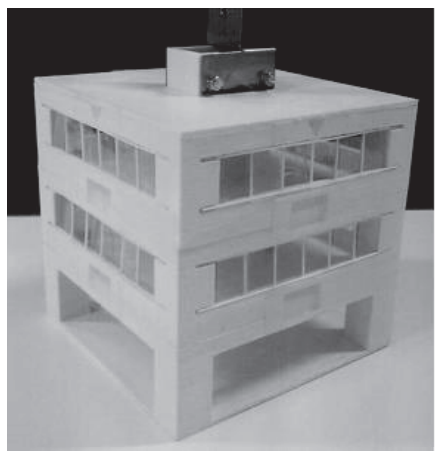

With piloti space
Photo 2 Experimental building model with glass windows

\section{2 造波水槽}

造波水槽は, 防衛大学校に設置されている全長 $17 \mathrm{~m}$, 幅 $0.4 \mathrm{~m}$, 高 さ $0.3 \mathrm{~m}$ の開水路型を使用した。造波水槽を Fig. 2 に示す。造波水槽 は大きく貯水部，水路部，陸上部に分かれている。貯水部は電動式攵 一ト（仕切板）を挟んで水深 $h_{0}$ と $h_{1}$ を設定するようになっており， 仕切板の急開により津波の模擬波を生成する。津波は貯水部から水路 部に入り,さらに陸上部一と遡上寸る。貯水部から水路部一は傾斜 $3 / 5$ の急斜面がある。水路部が乾燥している状態（ドライベッド）と水深 $30 \mathrm{~mm}$ で没水している状態（ウェットベッド）の 2 種類の入射波を考 えた。水路部から陸上部へは傾斜 $1 / 10$ の緩斜面がある。建物模型は 模型前面が陸上部の水平面始端から $0.6 \mathrm{~m}$ の位置に設置した。

\section{3 計測システム}

造波水槽内の流況を把握寸るために設置した容量式波高計，超音波 式波高計，およびプロペラ式流速計の位置を Fig.2 に記入した。仕切 板の位置を原点とし，津波の進行方向を正にとると，模型前面の位置 は+453cm である。容量式波高計は津波進行方向に 5 個直列に配置し， $-55 \mathrm{~cm}$ の位置に WG1, 水路部始端の位置に WG2, そこから $86 \mathrm{~cm}$ の 位置にWG3，陸上部始端の位置に WG4，そこから $50 \mathrm{~cm}$ の位置に WG5 を設置した。超音波式波高計は模型背面から $7.5 \mathrm{~cm}$ の位置に WG6S を 1個設置し, 設置高さは陸上部底面から $20 \mathrm{~cm}$ の位置とした。 容量式波高計は精度的に水底から $2 \mathrm{~cm}$ の範囲は測定不能であった。プ ロペラ式流速計は WG5 から $5 \mathrm{~cm}$ の位置に 1 個設置し, 設置高さは水 底から $2 \mathrm{~cm}$ とした。波高計と流速計の時系列データのサンプリング間 隔は 0.001 秒とした。

ピロティなし・開口部ありとピロティあり・開口部ありの建物模型 に取り付けた波圧計の位置を Fig.3に示す。ピロティなしの計測点は, 

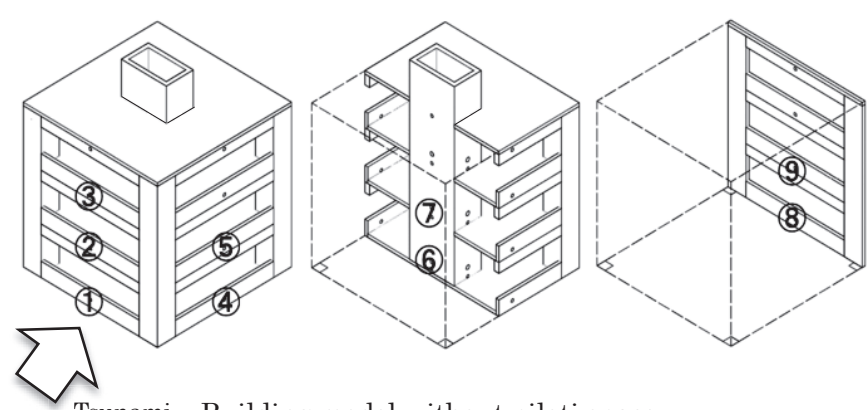

Tsunami Building model without piloti space
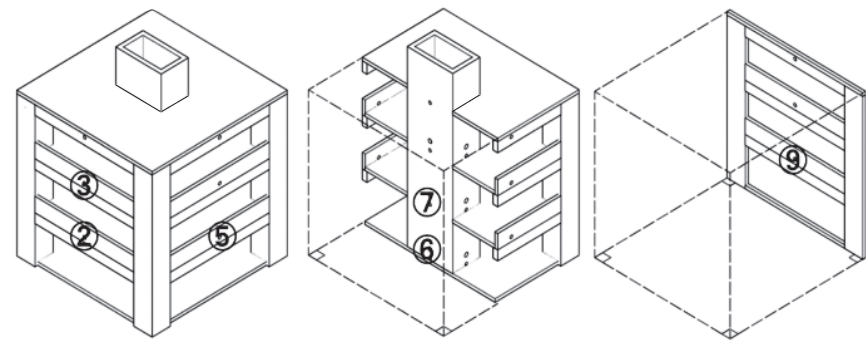

Building model with piloti space

Fig. 3 Mounting positions of wave pressure gauge

外壁前面の 1 階(1) $\cdot 2$ 階(2) - 3 階(3), 外壁側面 1 階(4) 2 階(5), コア 1 階(6)・ 2 階(7), 外壁背面 1 階(8)・ 2 階(9)の 9 箇所, ピロティありの計 測点は 1 階の腰壁がなくなるため, 外壁前面の 2 階(2)・3 階(3), 外壁 側面 2 階(5), コア 1 階(6)・2 階(7), 外壁背面 2 階(9)の計 6 箇所である。 波圧計測のサンプリング間隔は 0.001 秒とし， $15 \mathrm{~Hz}$ 以上のノイズを ローパスフィルターにより除去した。

波力の計測では，建物上部のペントハウスの位置に 3 分力計（ロー ドセル）を固定し，津波の進行方向の水平波力 $\mathrm{F}_{\mathrm{x}}$ と上向きの鉛直力 $F_{z}$ の変化を追跡した。波力計測のサンプリング間隔は 0.001 秒とし, $15 \mathrm{~Hz}$ 以上のノイズをローパスフィルターにより除去した。

\section{4 実験方法}

造波水槽内に建物模型を設置する前に, フリーフィールドとしての 流沉を確認することを目的に予備実験を行い，その後，建物模型を設 置して波圧実験と波力実験の 2 段階に分けて本実験を実施した。計測 時間は仕切板の急開から 20 秒間とし，3 回の再現性の高いデータが

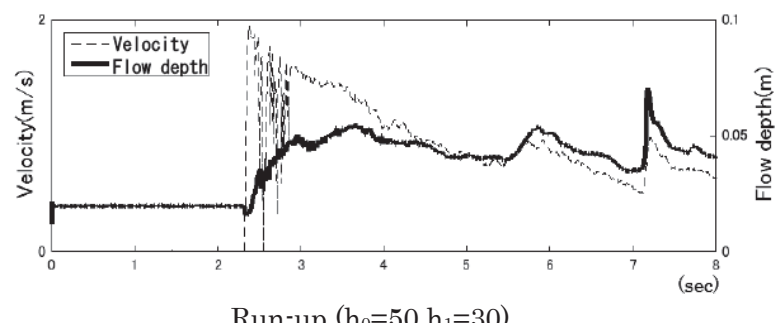

Run-up $\left(\mathrm{h}_{0}=50, \mathrm{~h}_{1}=30\right)$

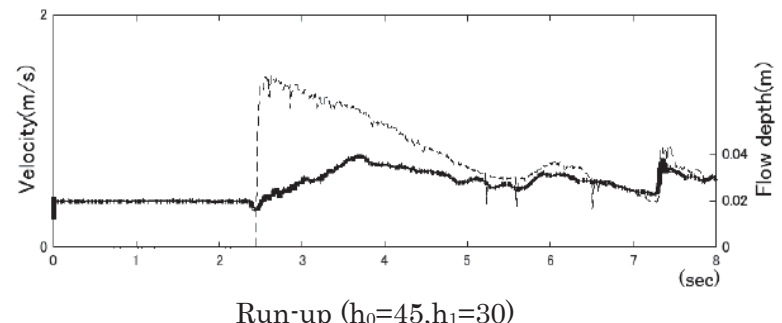

Table 1 Maximum flow depth and velocity in freefield

\begin{tabular}{c|c|c|c|c|c|c}
\hline $\begin{array}{c}\text { Wave } \\
\text { type }\end{array}$ & $\begin{array}{c}\mathrm{h}_{0} \\
{[\mathrm{~cm}]}\end{array}$ & $\begin{array}{c}\mathrm{h}_{1} \\
{[\mathrm{~cm}]}\end{array}$ & $\begin{array}{c}\text { Exp. } \\
\mathrm{d}_{\max }[\mathrm{m}]\end{array}$ & $\begin{array}{c}\text { Full-scale } \\
\mathrm{d}_{\max }[\mathrm{m}]\end{array}$ & $\begin{array}{c}\text { Exp. } \\
\mathrm{U}_{\max }[\mathrm{m} / \mathrm{s}]\end{array}$ & $\begin{array}{c}\text { Full-scale } \\
\mathrm{U}_{\max }[\mathrm{m} / \mathrm{s}]\end{array}$ \\
\hline Run-up & 50 & 30 & 0.0546 & 4.37 & 1.79 & 16.0 \\
\hline Bore & 50 & 33 & 0.0399 & 3.19 & 1.48 & 13.2 \\
\hline Run-up & 45 & 30 & 0.0596 & 4.77 & 1.74 & 15.6 \\
\hline Bore & 45 & 33 & 0.0408 & 3.26 & 1.43 & 12.8 \\
\hline
\end{tabular}

得られるまで計測を続けた。

津波の模擬波生成に当たっては, 貯水部の仕切板後方の浸水深 $\mathrm{h}_{0}$ を $50 \mathrm{~cm}$ と $45 \mathrm{~cm}$ とし，いずれの場合も仕切板前方の浸水深 $\mathrm{h}_{1}$ を $30 \mathrm{~cm}$ （水路部はドライベッド）としたときと $33 \mathrm{~cm}$ （水路部はウェットベ ッド）としたときの 2 通りで波圧と波力を計測した。以下では，水路 部がドライベッドのときの波を遡上波（Run-up）， ウェットベッドの ときの波を砕波段波（Bore）と呼ぶことにする。水路部がドライベッ ドのときは水路部で緩やかな角度の波となり, ウェットベッドのとき は急斜面終端で巻き波型の砕波が発生して波形先端が切り立った形 となる。

本実験で計測した物理量は, 建物模型前面の浸水深と流速, 建物前 方・後方での浸水深，波圧実験では建物内外で発生する波圧，波力実 験では建物全体に作用する水平波力と鉛直力である。

波圧実験の目的は，津波作用時に建物内外の特定の位置に作用寸る 波圧を計測することにより，波圧の空間分布と時間変化を把握するこ とである。水槽上部に組んだ鉄骨フレームから治具を介して建物模型 を下方に押し込み，模型底面を陸上部床面に密着させた。建物模型は ピロティなし・開口部ありとピロティあり・開口部ありを用い，開口 部はガラス空ありとガラス空なしの状態で実験を行った。

波力実験の目的は，津波作用時に建物全体に作用する波力を計測す ることにより，水平波力と鉛直力の時間変化を把握することである。 水槽上部の鉄骨フレームに 3 分力計を取り付け, ペントハウスを介し て建物模型を陸上部床面から $3 \mathrm{~mm}$ 浮かせた。建物模型はピロティな し・開口部なし, ピロティなし・開口部あり, およびピロティあり・ 開口部ありを用い, 開口部はガラス空なしの状態で実験を行った。

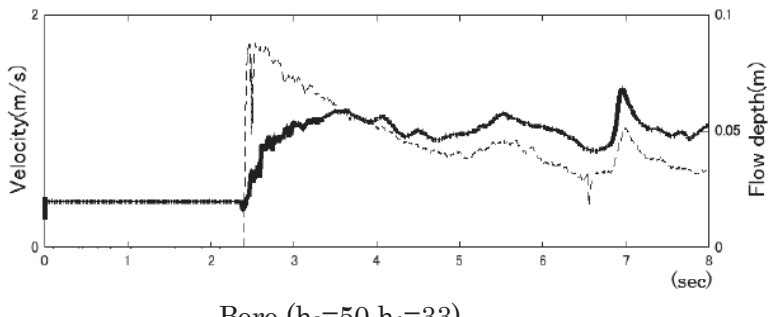

Bore $\left(\mathrm{h}_{0}=50, \mathrm{~h}_{1}=33\right)$

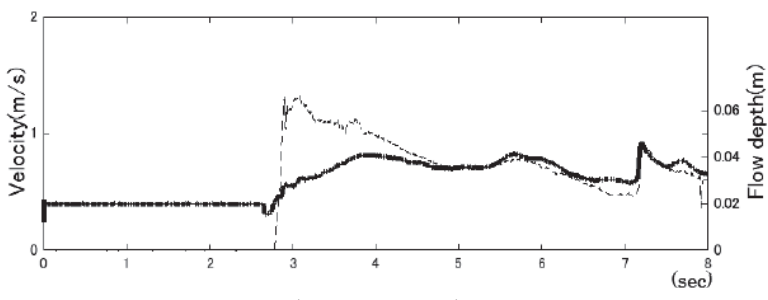

Bore $\left(\mathrm{h}_{0}=45, \mathrm{~h}_{1}=33\right)$

Fig. 4 Time variation of flow depth and velocity in freefield 


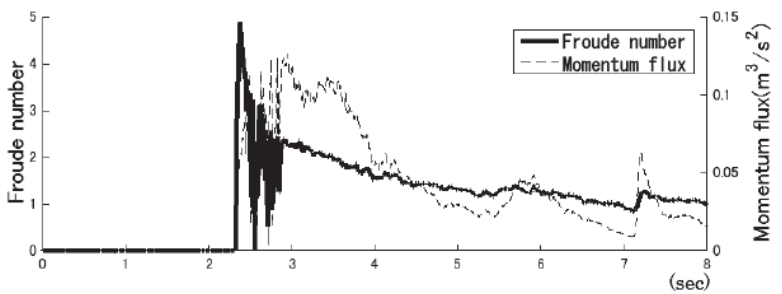

Run-up $\left(\mathrm{h}_{0}=50, \mathrm{~h}_{1}=30\right)$

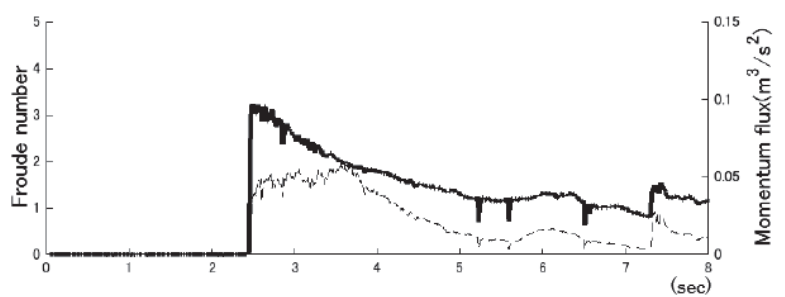

Run-up $\left(\mathrm{h}_{0}=45, \mathrm{~h}_{1}=30\right)$

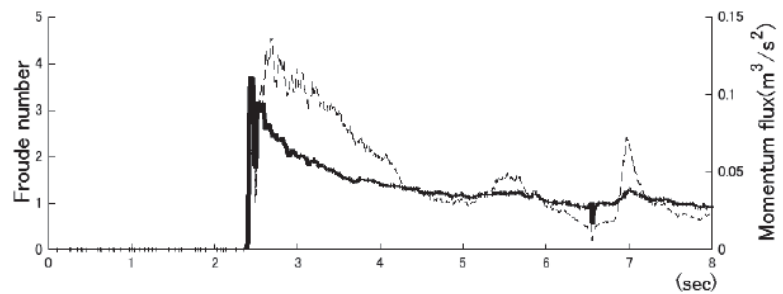

Bore $\left(\mathrm{h}_{0}=50, \mathrm{~h}_{1}=33\right)$

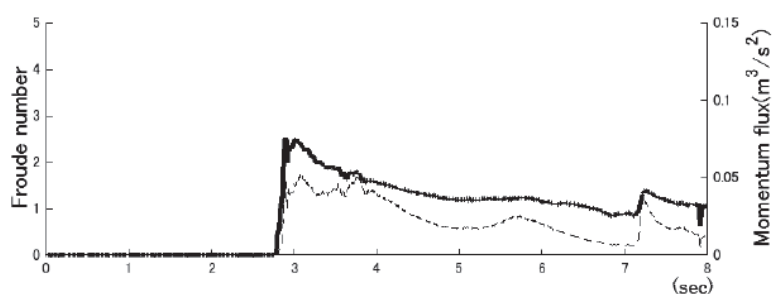

Bore $\left(\mathrm{h}_{0}=45, \mathrm{~h}_{1}=33\right)$

Fig. 5 Time variation of Froude number and momentum flux in freefield

\section{3. 実験結果}

\section{1 フリーフィールドでの流況}

建物模型が存在しないフリーフィールドの状態で，遡上波と砕波段 波に対する模型位置における浸水深と流速の時間変化を Fig.4 に示す。 $\mathrm{h}_{0}$ は $50 \mathrm{~cm}$ と $45 \mathrm{~cm}$ とした。いずれも流速が最大になった後に浸水深 が最大になっている。7 秒近傍に見られるピークは仕切板からの後退 波が貯水部後壁に当たって発生した反射波である。最大浸水深と最大
流速を Table 1 に示す。実験值とともに相似則に基づく実際值 (Full-scale) も示した。

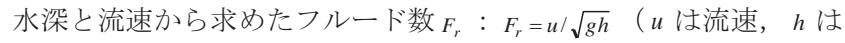
浸水深， $\mathrm{g}$ は重力加速度）と運動量フラックス $M$ ： $M=u^{2} h$ の時間変 化を Fig. 5 に示寸。フルード数の立ち上がりと減衰は速く, 運動量フ ラックスの変化は相対的にゆるやかである。フルード数と運動量フラ ックスの大きさの変化には時間的なずれが生じることがわかる。また，

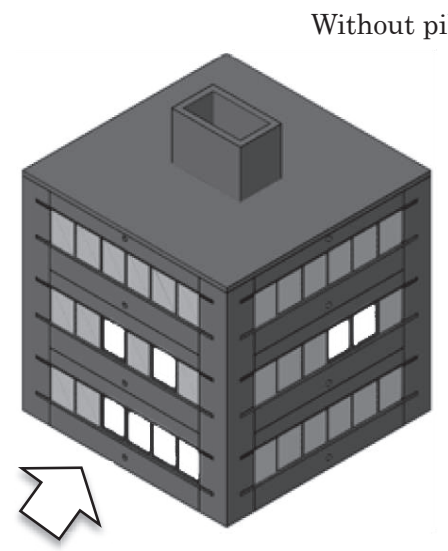

piloti space

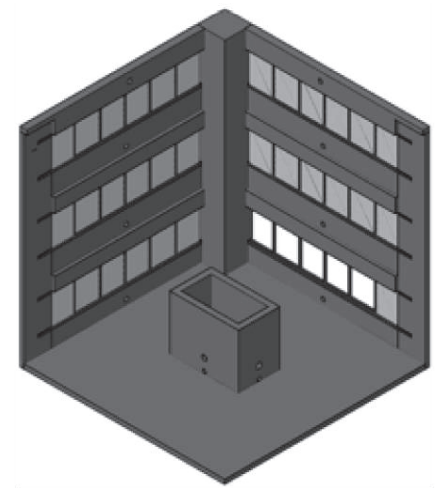

Tsunami Run-up $\left(\mathrm{h}_{0}=50, \mathrm{~h}_{1}=30\right)$
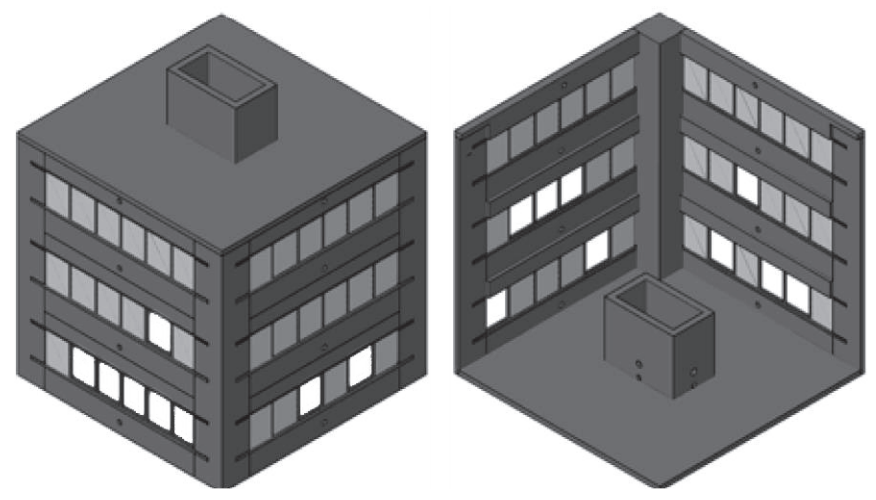

Bore $\left(\mathrm{h}_{0}=50, \mathrm{~h}_{1}=33\right)$

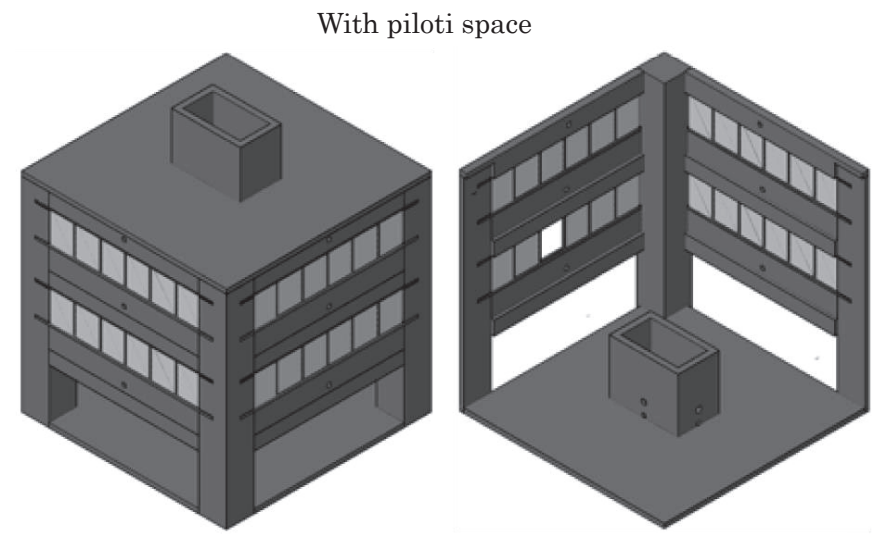

Run-up $\left(\mathrm{h}_{0}=50, \mathrm{~h}_{1}=30\right)$
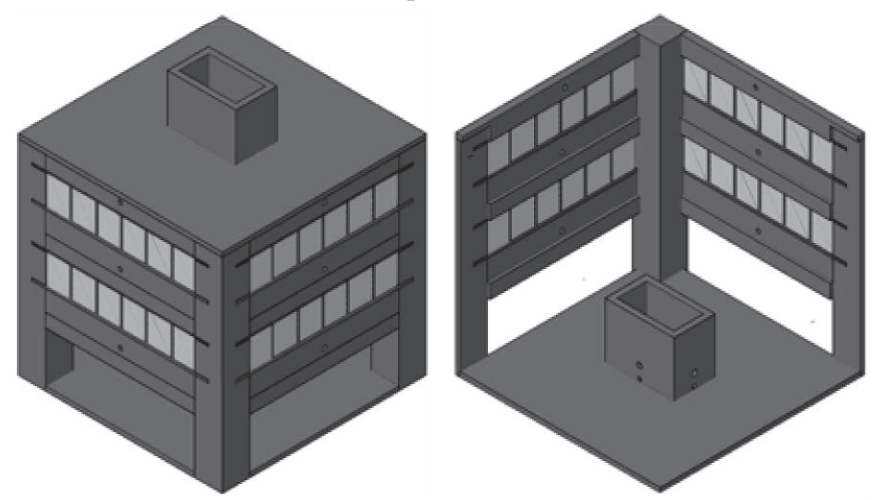

Bore $\left(\mathrm{h}_{0}=50, \mathrm{~h}_{1}=33\right)$

Fig. 6 Difference in washout patterns of glass windows in case with or without piloti space 
With glass windows

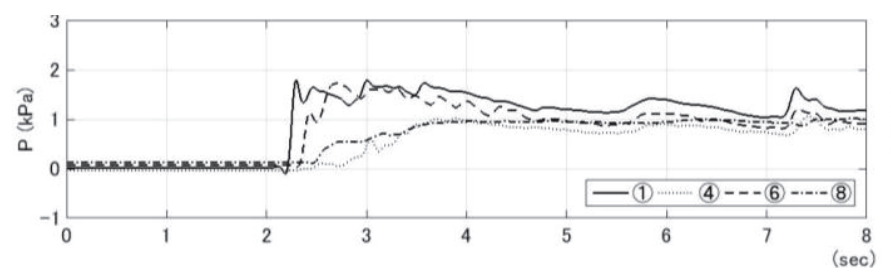

Run-up $\left(\mathrm{h}_{0}=50, \mathrm{~h}_{1}=33\right)$

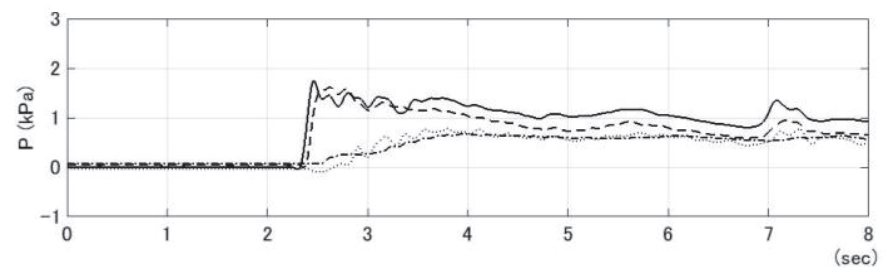

Bore $\left(\mathrm{h}_{0}=50, \mathrm{~h}_{1}=33\right)$
Without glass windows

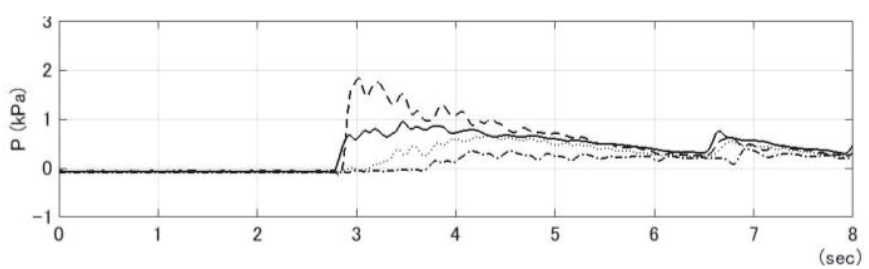

Run-up $\left(\mathrm{h}_{0}=50, \mathrm{~h}_{1}=33\right)$

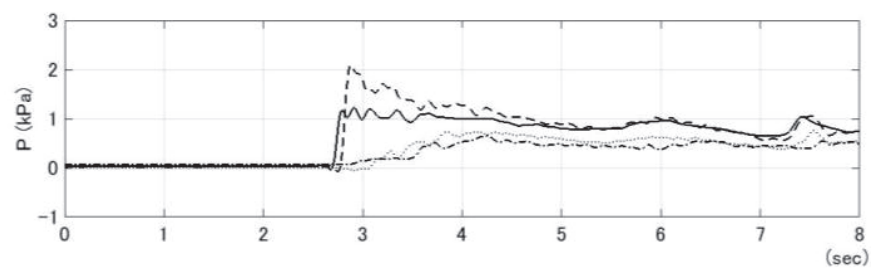

Bore $\left(\mathrm{h}_{0}=50, \mathrm{~h}_{1}=33\right)$

Fig. 7 Time variation of wave pressure in case without piloti space

With glass windows

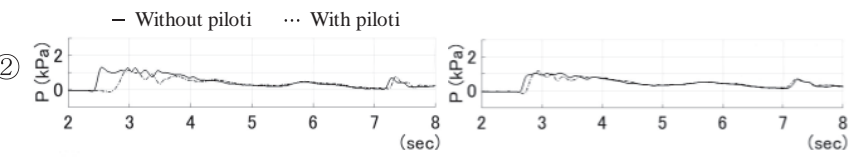

(3) $\frac{\stackrel{D}{0}^{0}}{0_{0}^{2}}$

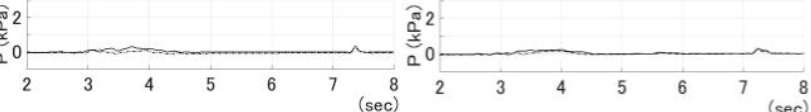

(5)

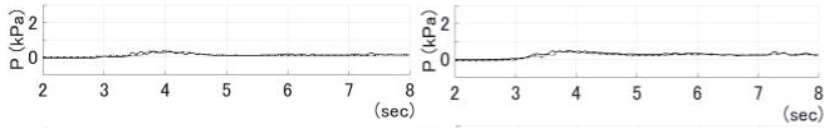

(6)

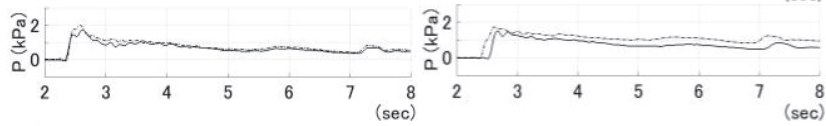

(7)

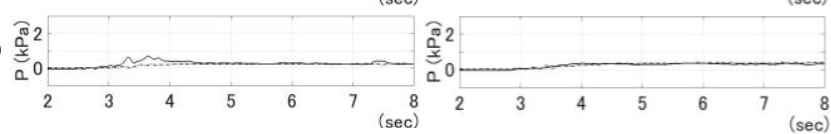

(9)

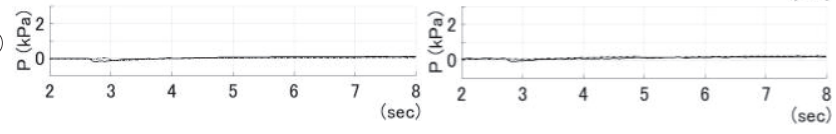

Fig. 8 Time variation of wave pressure in case with or without glass windows

フルード数が 1 を下回ることはほとんどなく, いずれも射流 $\left(F_{\mathrm{r}}>1\right)$ の状態での実験となっている。

\section{2 ガラス窓の流失パターン}

建物模型を水槽に設置して, 遡上波と砕波段波に対する模型前面の 浸水深を計測した。模型前面での浸水深は, 模型がないときに比べ, ピロティなし・開口部なしでは約2.6倍, ピロティなし・開口部あり（ガ ラス空なし) では約1.9倍, ピロティあり・開口部あり (ガラス空なし) では約1.6倍となり, 開口率が大きくなるほど上階への影響は小さくな った。

開口部にガラス空を取り付け, ガラス空の流失パターンを観察した。 ピロティありとピロティなしのガラス空の流失パターンの一例を Fig.6に示す。ピロティなしのときは，流失したガラス空は1階に集中 しており，遡上波も砕波段波も前面での流出が顕著である。しかし， 遡上波では背面からの流出も多く, 砕波段波では側面からの流失も多 かった。津波が建物に浸入した後の流況を反映している。ピロティあ
Without glass windows

(2) $\frac{\overparen{\infty}}{\frac{0}{2}}$

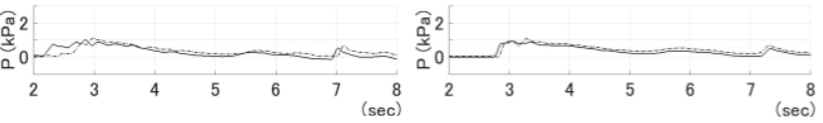

(3) $\stackrel{\sqrt{0}}{\stackrel{2}{\Sigma}}$

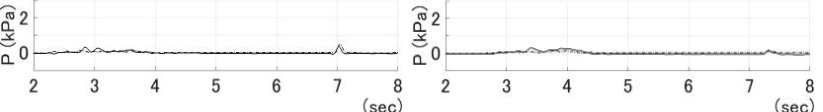

(5)

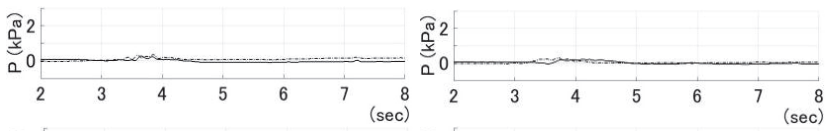

(6) $\frac{\sqrt[\pi]{0}}{\stackrel{0}{*}}$

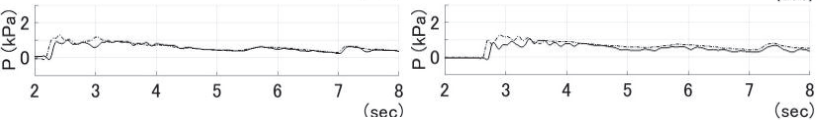

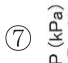

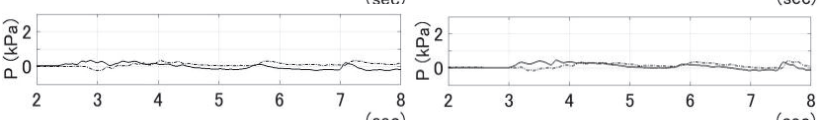

(9)

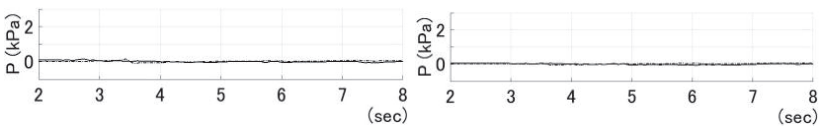

りは, ピロティなしで部分的に流失していた 2 階と3階のガラス空の多 くが流出を免れている。これは, 津波が1階を通り抜けたことにより, 浸水深の上昇と上階へのせき上げ効果が低減したためと考えられる。

\section{3 部位に作用する波圧の時間変化}

ピロティなしのときに建物 1 階の前面(1)，側面(4)，コア(6)，および 背面(8)生じる波圧の時間変化をガラス空ありとガラス空なしにつ いて Fig.7 に示す。ガラス空ありのときは前面(1)で大きな立ち上がり を示し, 少し遅れてコア(6)が同程度の大きさで立ち上がっている。ガ ラス空なしのときは前面(1)での立ち上がりが小さくなり、すぐにコア (6)で(1)の 2 倍程度の立ち上がりが生じている。側面(4)之背面(8)の波圧 はゆっくりと上昇している。遡上波と砕波段波の違いは小さい。

ガラス空があるときとないときの建物の 2 階(2)と 3 階(3)，側面の 2 階(5), コアの 1 階(6) と 2 階(7), 背面の 2 階(9)の波圧の時間変化を Fig.8 に示す。コア 1 階(6)に比べると 2 階以上での波圧は概して小さいが, 前面の 2 階(2)では比較的大きな值を示している。とくに, ピロティが 
Table 2 Maximum values of horizontal and vertical wave force

\begin{tabular}{c|c|c|c|c|c}
\hline Model & Wave & $\begin{array}{c}\text { Exp. } \\
\mathrm{F}_{\mathrm{x}}[\mathrm{N}]\end{array}$ & $\begin{array}{c}\text { Full-scale } \\
\mathrm{F}_{\mathrm{x}}[\mathrm{kN}]\end{array}$ & $\begin{array}{c}\text { Exp. } \\
\mathrm{F}_{\mathrm{z}}[\mathrm{N}]\end{array}$ & $\begin{array}{c}\text { Full-scale } \\
\mathrm{F}_{\mathrm{z}}[\mathrm{kN}]\end{array}$ \\
\hline \multirow{4}{*}{$\mathrm{I}$} & $\mathrm{R}(50,30)$ & 17.98 & 9206 & 7.79 & 3989 \\
\cline { 2 - 6 } & $\mathrm{B}(50,33)$ & 6.41 & 3283 & 7.14 & 3654 \\
\cline { 2 - 6 } & $\mathrm{R}(45,30)$ & 15.47 & 7921 & 8.39 & 4295 \\
\cline { 2 - 6 } & $\mathrm{B}(45,33)$ & 6.52 & 3339 & 6.34 & 3247 \\
\hline \multirow{4}{*}{ II } & $\mathrm{R}(50,30)$ & 13.67 & 6999 & -8.80 & -4503 \\
\cline { 2 - 6 } & $\mathrm{B}(50,33)$ & 5.77 & 2953 & -4.56 & -2334 \\
\cline { 2 - 6 } & $\mathrm{R}(45,30)$ & 13.49 & 6907 & -9.78 & -5007 \\
\cline { 2 - 6 } & $\mathrm{B}(45,33)$ & 5.47 & 2801 & -4.92 & -2520 \\
\hline & $\mathrm{R}(50,30)$ & 11.50 & 5888 & -7.28 & -3727 \\
\cline { 2 - 6 } & $\mathrm{B}(50,33)$ & 4.50 & 2301 & -3.34 & -1710 \\
\cline { 2 - 6 } & $\mathrm{R}(45,30)$ & 10.54 & 5386 & -6.01 & -3076 \\
\cline { 2 - 6 } & $\mathrm{B}(45,33)$ & 4.01 & 2055 & -3.21 & -1643 \\
\hline
\end{tabular}

$\mathrm{I}$ : Without piloti and without openings $\mathrm{R}\left(\mathrm{h}_{0}, \mathrm{~h}_{1}\right)$ : Run-up $\left(\mathrm{h}_{0}, \mathrm{~h}_{1}\right)$

II : Without piloti and with openings $\quad \mathrm{B}\left(\mathrm{h}_{0}, \mathrm{~h}_{1}\right)$ : $\operatorname{Bore}\left(\mathrm{h}_{0}, \mathrm{~h}_{1}\right)$

III: With piloti and with openings

ないときの立ち上がりは急激で大きく, ガラス空ありでその傾向が顕 著に見られる。

\section{4 最大波圧の空間分布}

波圧計を設置した位置に生じた最大波圧とその発生時刻を Fig.9 に 示す。最大波圧の大きさから建物の各部位に作用する波圧の空間分布 を概略把握することができる。ピロティなしの場合，ガラス㲅がある と 1 階腰壁の最大波圧が生じた後， 2 階腰壁と 1 階コアに同程度の最 大波圧が生じている。ガラス空がないと 1 階腰壁と 2 階腰壁の最大波 圧が生じた後，1階コアにその 2 倍程度の最大波圧が生じている。ピ ロティありの場合，ガラス空のありなしに関わらず，1階コアの最大

Without piloti space and with glass windows
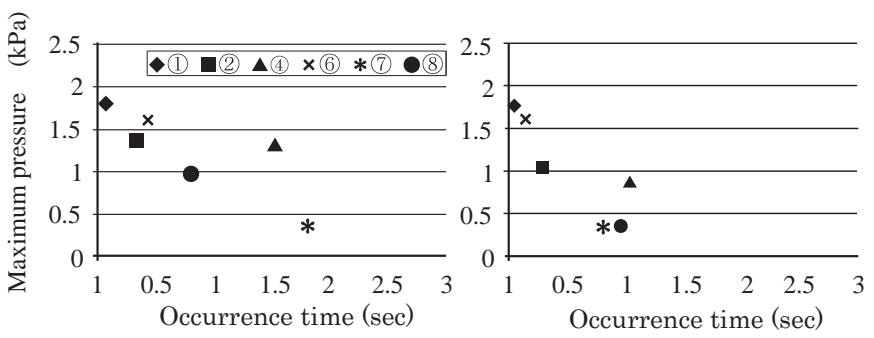

Run-up $\left(\mathrm{h}_{0}=50, \mathrm{~h}_{1}=30\right)$

Bore $\left(\mathrm{h}_{0}=50, \mathrm{~h}_{1}=33\right)$

Without piloti space and without glass windows

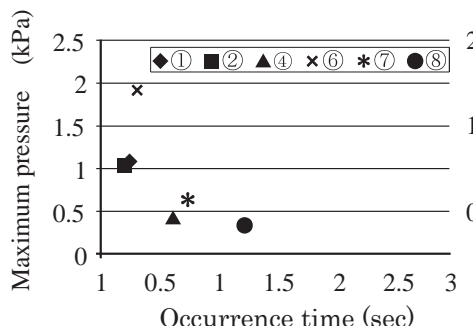

Occurrence time (sec)

Run-up $\left(\mathrm{h}_{0}=50, \mathrm{~h}_{1}=30\right)$

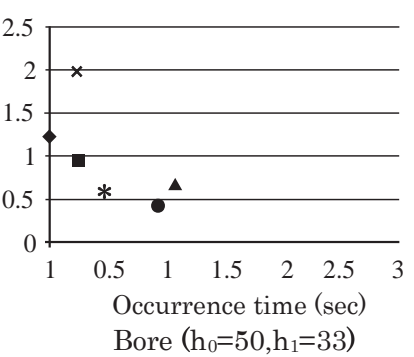

波圧が生じた後， 2 階腰壁にその $2 / 3$ 程度の最大波圧が生じている。

\section{5 水平波力と鉛直力の時間変化}

ピロティなし・開口部なし，ピロティなし・開口部あり，およびピ ロティあり・開口部ありのそれぞれの場合の遡上波と砕波段波に対す る水平波力と鉛直力の時間変化を Fig.10 に示す。開口部なしでは鈆 直力は上向きに，開口部ありでは鉛直力は下向きに作用している。こ れは，開口部なしでは浮力のみが作用するのに対し，開口部ありでは 内部に流入した水により浮力の大きさを上回る重力が作用するため である。水平波力の最大值に比べ鉛直力の最大值は遅れて発生してい る。水平波力と鉛直力の最大值を Table 2 に示寸。ピロティなし・開 口部ありはピロティなし・開口部なしに比べて水平波力が約 $20 \%$ 低減 し，ピロティあり・開口部ありでは水平波力が約 $35 \%$ 低減している。

\section{6 波力の評価}

\section{6.1 水平波力の評価}

抗力による推定式8) と静水圧分布による推定式9)を用いて最大水平 波力を推定する。抗力による推定には次式を用いた。

$$
\mathrm{F}_{\mathrm{x}}=\frac{\mathrm{C}_{\mathrm{d}}}{2} \rho \mathrm{U}^{2} \mathrm{~S}_{\mathrm{d}}
$$

ここに, $F_{x}$ は水平波力, $\rho$ は水の密度, $U$ は通過波の流速, $\mathrm{S}_{\mathrm{d}}$ は 津波進行方向から見た受圧部分の面積, $C_{d}$ は次式で与えられる抗力 係数である。

$$
C_{d}=2.0+5.4 \frac{d_{\max }}{D}
$$

ここに， $\mathrm{d}_{\max }$ は通過波の最大水深，Dは汀線からの距離である。

静水圧分布による推定には次式を用いた。

$\mathrm{F}_{\mathrm{x}}=\frac{1}{2} \alpha\left(3 \rho \mathrm{g} \mathrm{d}_{\max }\right) \cdot\left(3 \mathrm{~d}_{\max }\right) \mathrm{B}$

ここに， $\alpha$ は模型の非開口率， $\mathrm{g}$ は重力加速度， $\mathrm{B}$ は建物幅である。

上記の 2 種類の推定方法を用いて, 受圧部分の面積としてコアを考

With piloti space and with glass windows

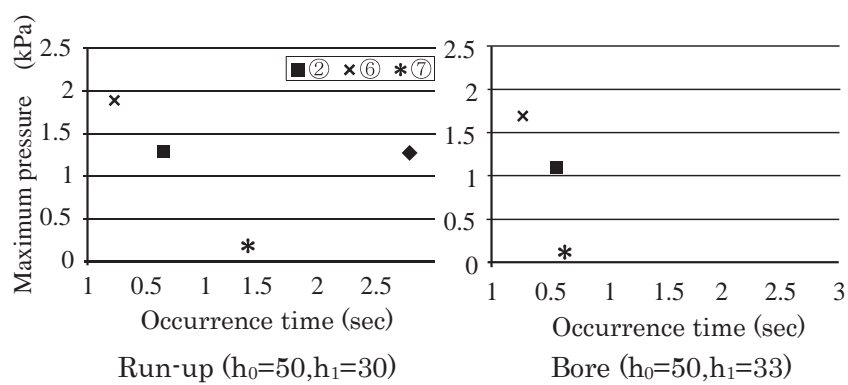

With piloti space and without glass windows

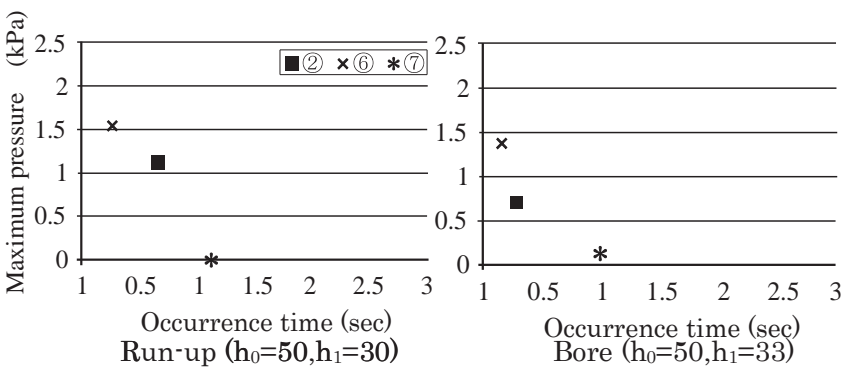

Fig. 9 Distribution of maximum wave pressure and its occurrence time 
Run-up $\left(\mathrm{h}_{0}=50, \mathrm{~h}_{1}=30\right)$

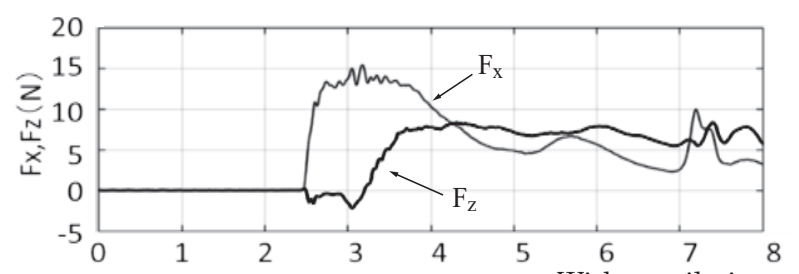

Bore $\left(\mathrm{h}_{0}=50, \mathrm{~h}_{1}=33\right)$

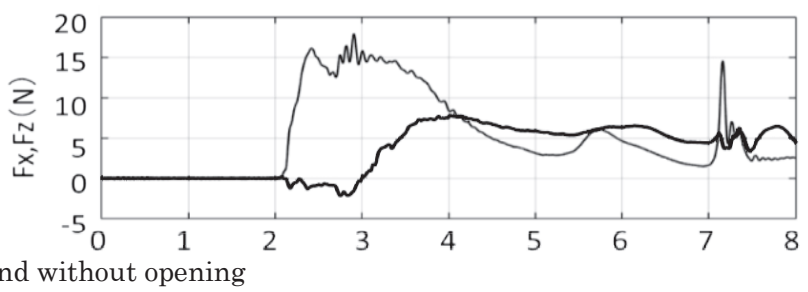

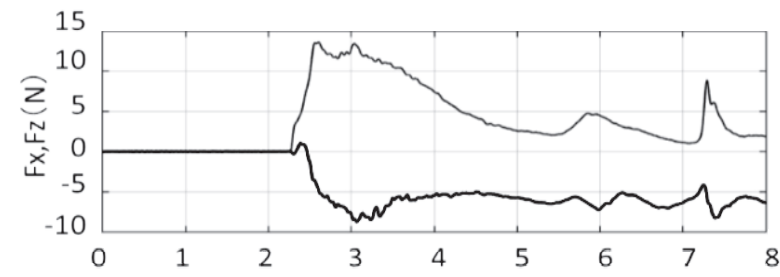
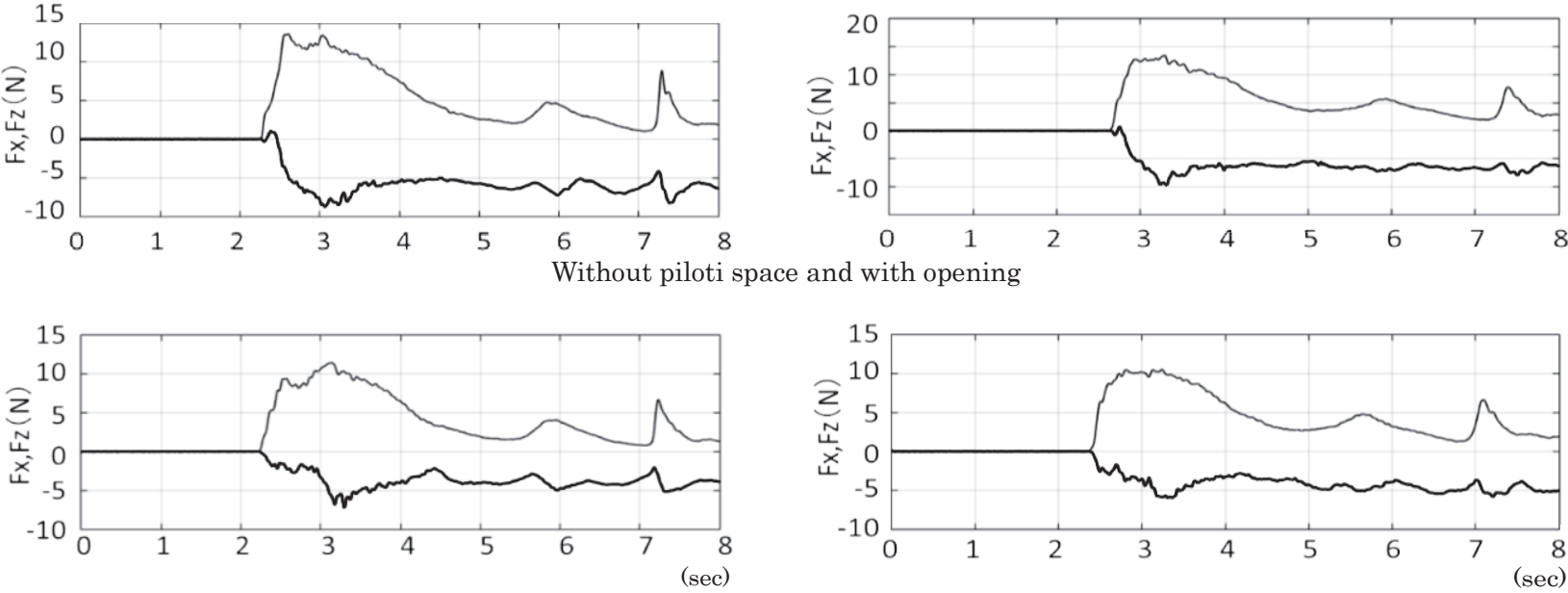

With piloti space and with opening

Fig. 10 Time variation of horizontal and vertical forces

慮した場合としない場合を比較したところ，Fig.11に示すように，コ アを考慮することにより安全側の評価になっている。水平波力の評価 においては, 内壁の存在による波力の増減を適切に評価することが重 要である。

\subsection{2 鉛直力の評価}

最大鈆直力の推定5にには次式を用いた。

$$
\mathrm{F}_{\mathrm{z}}=\frac{1}{2} \rho g \mathrm{~d}_{\mathrm{f}} \mathrm{A}
$$

ここに, $F_{B}$ は鉛直力, $A$ は底面の面積, $d_{f}$ は建物前面の浸水深で水 平波力 $\mathrm{F}_{\mathrm{X}}$ を静水圧分布に置き換えることにより次式で与えられる。

$$
d_{f}=\sqrt{2 F_{x} / \rho g}
$$

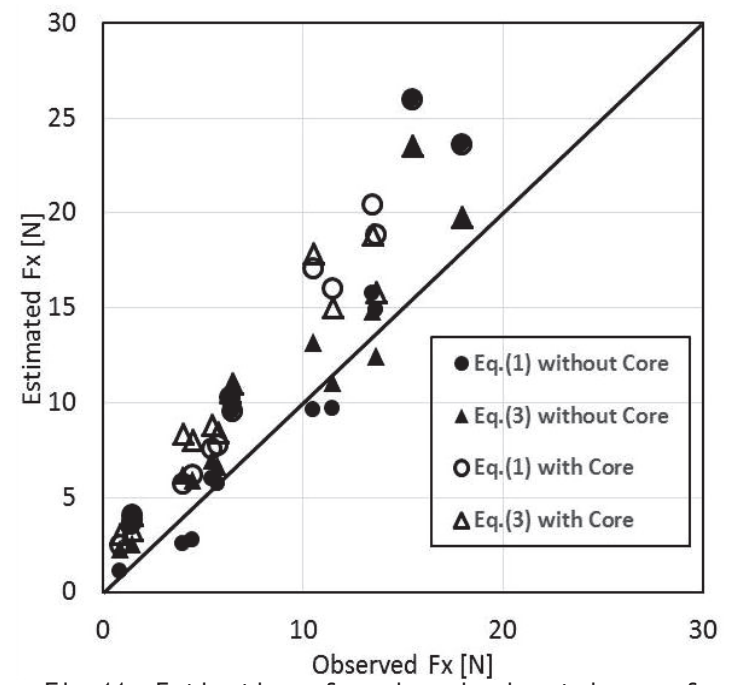

Fig. 11 Estimation of maximum horizontal wave forces
また，模型背面の浸水深が前面の浸水深と同じであるとして次式を 用いた推定も行った。

$$
\mathrm{F}_{\mathrm{z}}=\rho \operatorname{gd}_{\mathrm{f}} \mathrm{A}
$$

なお，推定に用いる $F_{x}$ には，実測值，抗力による推定值，および静 水圧分布による推定值の 3 種類の值を採用し, 水の重量は模型が没水 している部分の体積から求めた。その結果, Fig.12 に示寸ように, 模型背面の浸水深が前面の浸水深と同じと考えると最大で約 2 倍の 過大評価となり, 背面の浸水深を 0 とすると危険側の評価になってい る。鉛直力の評価においては, 建物後方に回り込む津波の浸水深を適 切に評価することが重要である。

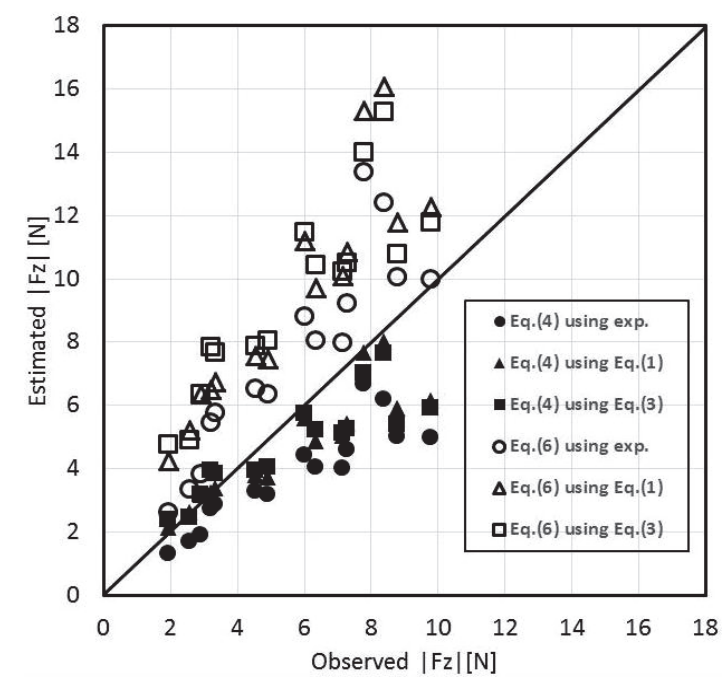

Fig. 12 Estimation of maximum vertical forces 


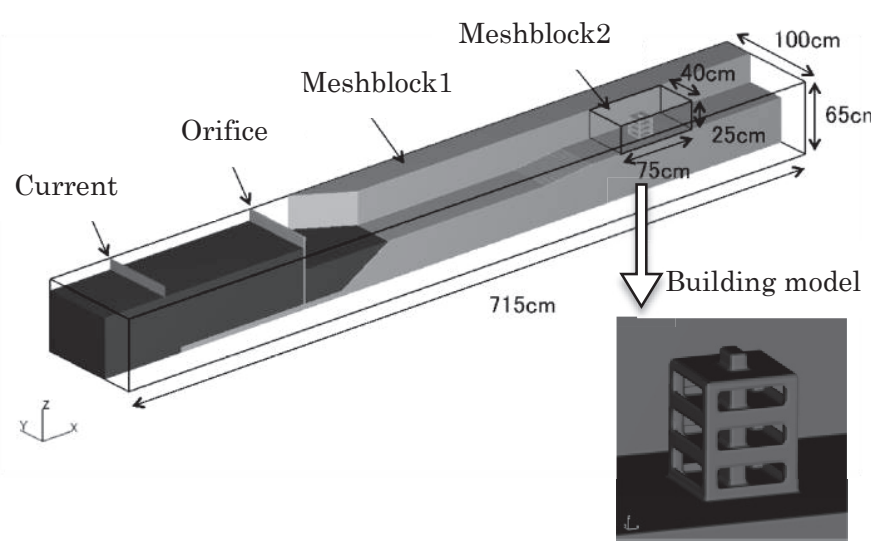

Fig. 13 Analytical domain for numerical simulation

Run-up $\left(\mathrm{h}_{0}=50, \mathrm{~h}_{1}=30\right)$

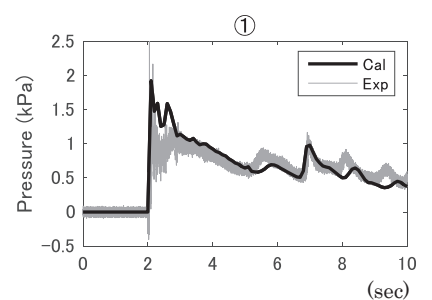

(2)
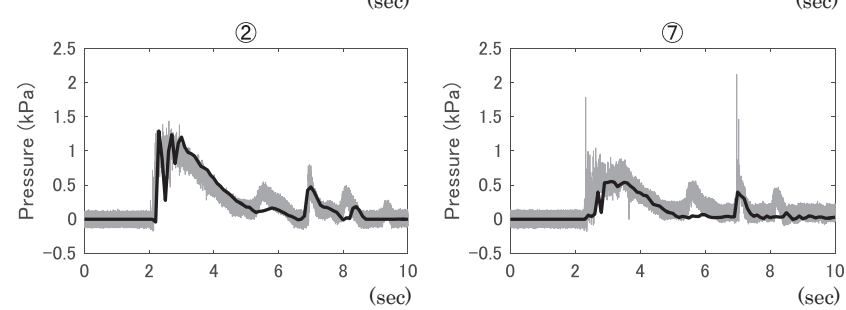

\section{4. 解析との比較}

\section{1 解析モデル}

遡上波と砕波段波に対し, ピロティなし・開口部ありとピロティ あり・開口部ありのときの津波シミュレーション解析を行った。実 験を再現するために対象とした解析領域を Fig.13に示す。水槽の貯 水部から建物模型後方の一定範囲までを解析領域とした。計算格子 は可変メッシュとし，メッシュブロック 1 では水平 $20 \sim 30 \mathrm{~mm}$, 鈆 直 $6 \mathrm{~mm}$, メッシュブロック 2 では水平・鉛直ともに $3.5 \sim 5 \mathrm{~mm}$ とし た。仕切板については実験時の開門速度を測定した上で，開門過程 に時間を要する移動物体としてモデル化した。

\section{2 解析手法}

解析手法には Navier-Stokes 方程式と連続式を支配方程式とする 差分法を用いた。水面形状は VOF 法 10)で再現している。解析領域 の境界条件として，建物模型後方に流出条件を設定した。建物模型

Bore $\left(\mathrm{h}_{0}=50, \mathrm{~h}_{1}=33\right)$
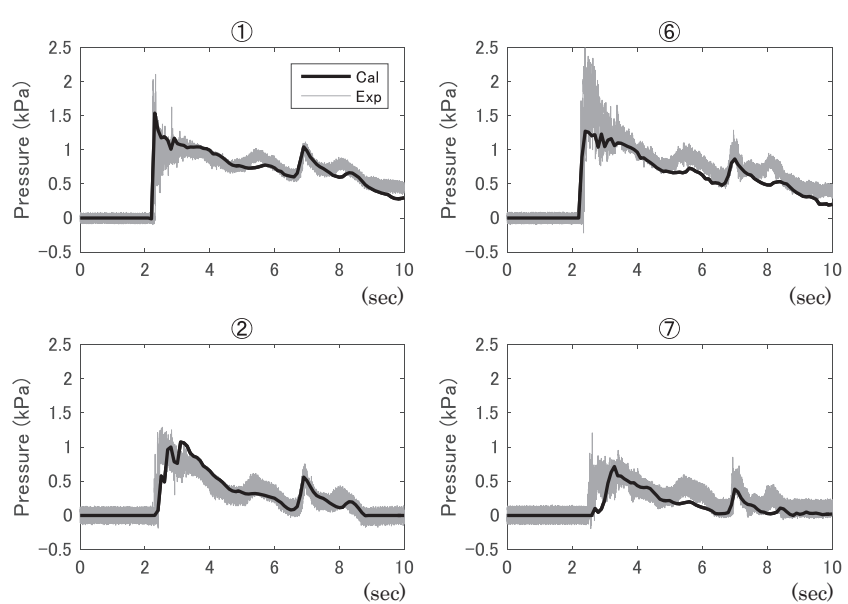

Fig. 14 Time variation of wave pressures at measured points (1), (2), (6) and (7)

Without piloti space and with opening

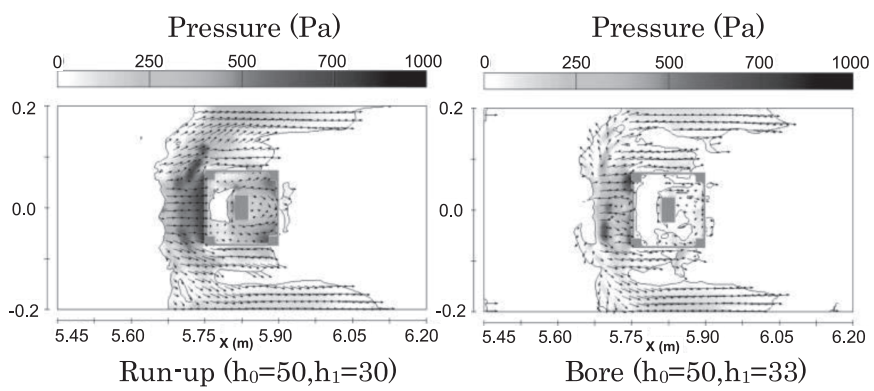

With piloti space and with opening
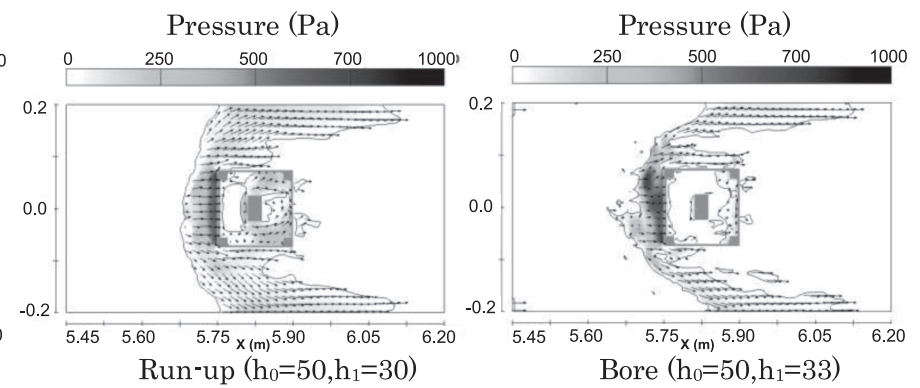

2nd floor$$
\text { . }
$$
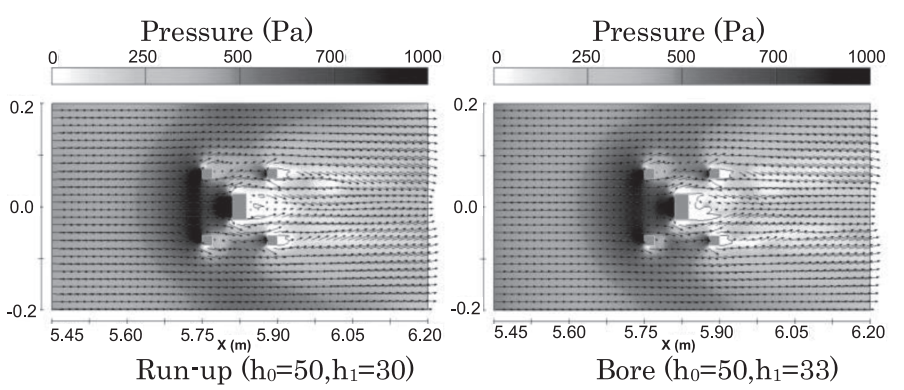

1st floor

Fig. 15 Horizontal distribution of wave pressure and flow velocity inside and outside of buildings with or without piloti space 
Without piloti space and with opening

Pressure $(\mathrm{Pa})$

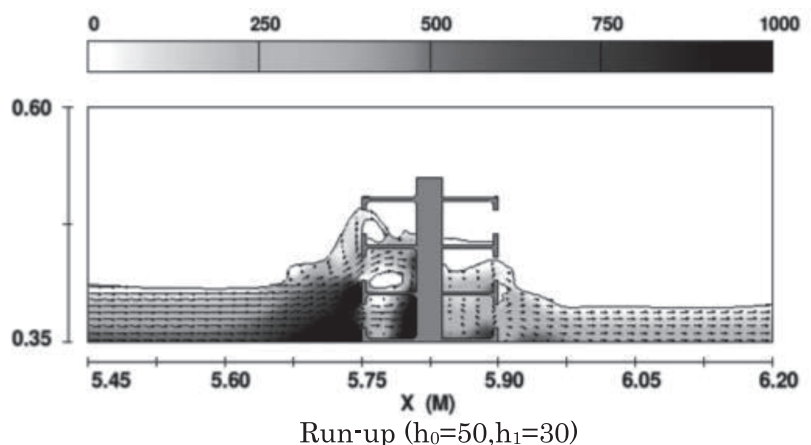

Run-up $\left(\mathrm{h}_{0}=50, \mathrm{~h}_{1}=30\right)$

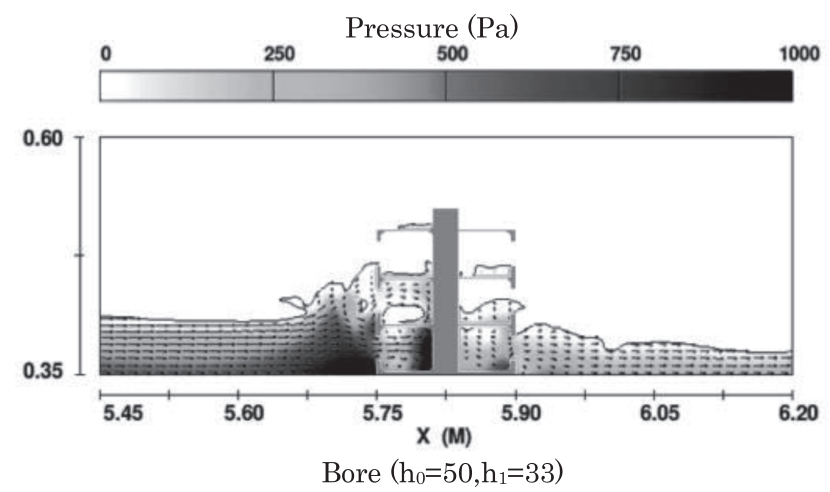

With piloti space and with opening

Pressure $(\mathrm{Pa})$
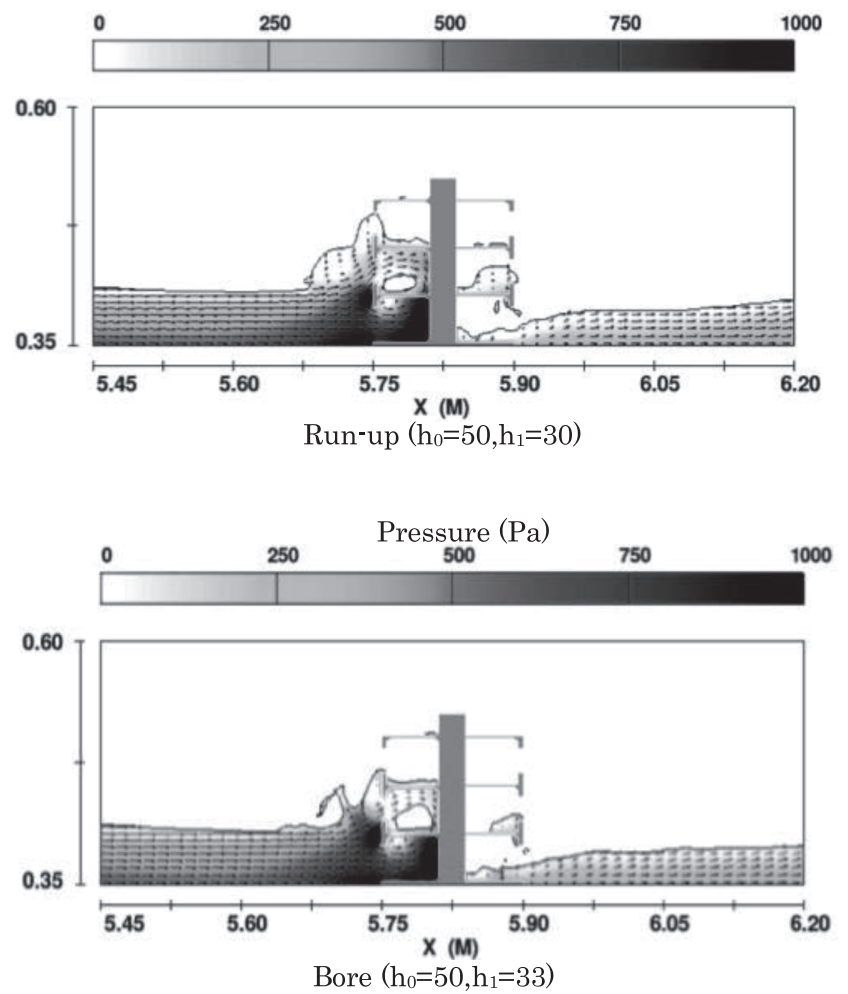

Fig. 16 Vertical distribution of wave pressure and flow velocity inside and outside of buildings with or without piloti space

の底面を密着させる方法と, 模型底面と水底の隙間を 1 メッシュ分

(3mm) 浮かせる方法の 2 通りで解析を行った。これは. 模型底面を 密着させると浮力を評価できなくなるためである。

\section{3 解析結果}

ピロティなし・開口部ありの状態で，建物模型の1階と2階の腰壁1 (2)と1階と2階のコア(6)(7)の前面に発生する波圧の時間変化を求め実 験結果とともにFig.14に示す。遡上波と砕波段波のいずれに対しても 建物模型の各部位における波圧の時間変化は十分再現されており, シ
ミュレーション解析により建物内外の任意の位置における波圧が精 度良く求まることが確認できた。

ピロティなし・開口部ありとピロティあり・開口部ありの状態で, 仕切り板開門から 3.0 秒後（建物前面に最大波圧が発生する時間帯） における 1 階と 2 階の波圧計取り付け高さにおける建物内外の波圧の 水平分布と流速ベクトルを Fig.15 に示す。ピロティがないと 1 階前 面の腰壁全体に大きな波圧が発生している。ピロティがあると，1階 前面柱と 1 階コア前面で波圧が部分的に大きくなり, 両者の間のスペ
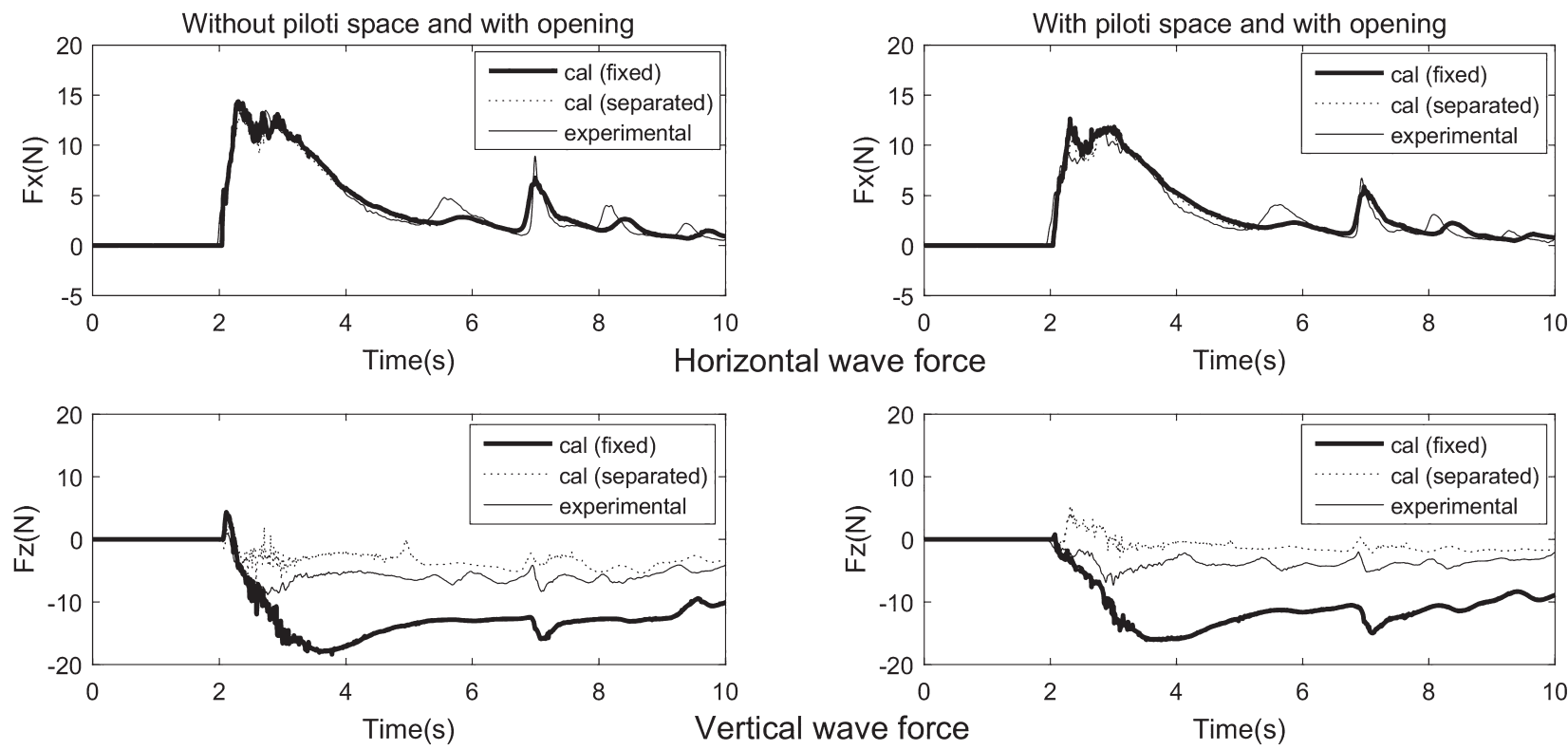

Fig. 17 Comparison of analytical and experimental values for horizontal and vertical wave forces 
ースで顕著な内圧上昇が見られる。2 階で発生する波圧は小さく, 後 方への津波の回り込みはほとんど見られない。腰壁とコアの波圧分布 は中央部で大きく端部で小さな円弧形である。建物内の流れはコアの 存在により向きを変えて側面に向った後, 再び津波の主方向に引き込 まれている。

ピロティなし・開口部ありとピロティあり・開口部ありの状態で, 仕切り板開門から 3.0 秒後における建物内外の波圧の鉛直分布と流速 ベクトルを Fig.16 に示す。高さ方向には静水圧的な波圧分布となっ ている。1 階は長時間完全没水, 2 階は短時間完全没水，3 階は部分没 水状態となった。ピロティがないと 1 階前面に作用する波圧が大きく, 1 階コアに作用寸る波圧は小さい。ピロティがあると，津波が 1 階コ アに直接作用して大きな波圧が生じている。2 階以上は前面でのせき 上げ効果により浸水しているが，背面は浸水深に達しておらず，その まま外部に排出されている。遡上波は段波よりも背面を内部から押す 波圧が大きく, 実験で観察された背面でのガラス空流失の原因を示唆 している。しかし，段波のときに側面のガラス空が流失した原因を裏 付けるような特徵は見出せなかった。

ピロティなし・開口部ありとピロティあり・開口部ありの状態で, 遡上波と砕波段波に対する建物模型の水平波力と鉛直力の時間変化 を求め実験結果とともに Fig.17 に示す。水平波力の解析值は実験值 とほぼ一致している。また，模型を浮かせた場合でも，水平波力に大 きな差は見られない。鉛直力は, 模型底面を水槽底面からわずかに浮 かせることにより浮力の影響を評価できている。しかし，実験結果と はまだ $2 \sim 5 \mathrm{~N}$ 程度の差が生じている。これは，実験における模型底面 と水槽底面の境界の不確定性や解析の 1 メッシュによる精度などが問 題と考えられる。

\section{5. 結び}

開口部と開放部の有無を組み合わせた 3 タイプの3層建物模型を製 作し，津波水槽実験を行い，建物内部に浸入した津波の流況，構造材 や非構造材に作用する局所的な波圧，建物全体に作用する水平波力と 鉛直力などに関して基礎的な検討を行った。さらに, 実験の状況を再 現した津波シミュレーション解析を行い, 実駼結果と比較した。本研 究の範囲内で得られた知見を以下に要約する。

1) ピロティがあると浸水深の上昇と上階へのせき上げ効果が低減 し，波圧の作用領域が小さくなる。

2) ガラス空の破壊により，1階腰壁に作用する波圧は減少し，1階コ アに作用する波圧は増加する。

3）ガラス空が壊れにくいと建物内部一の浸水は遅れるが, 浸水深の 上昇とせき上げ効果により上階に作用寸る波圧は大きくなる。

4) ピロティの有無にかかわらず, 建物内部のコアに生じる最大波圧 は外壁に生じる最大波圧と同程度か大きくなる傾向が見られる。

5)建物1階前面から浸入した津波は，コアに当たって側方に流れを
変えた後, 流速の強弱により側面あるいは背面の開口部から排出 される。

6) 水平波力は，開口部なしのときに比べ，ピロティがないとき（開 口率37\%）は約20\%，ピロティがあるとき（開口率44\%）は約35\% それぞれ低減する。

7)開口部がないと大きな上向きの浮力が発生するが, 開口部がある と内部浸水した水の重量が勝り下向きの鉛直力として作用する。

8) 水平波力の推定に当たっては, 外壁だけではなく内壁も適切に受 圧面に含める必要がある。

9）VOF法を用いた津波シミュレーション解析は, 建物の各部位に作 用するローカルな波圧も建物全体に作用するグローバルな波力 も精度良く再現できる。

10) 津波シミュレーション解析により, 実験では限定された位置でし か測定できない波圧や流速の空間分布を詳細に推定できる。

11）解析モデルを地面からわずかに浮かせることにより, 建物に作用 する鉛直力における内部浸水の影響を評価することができる。

\section{謝辞}

本研究を進めるにあたり，模型の設計，実験の実施，およびデータ 収集・整理に尽力した当時東京都市大学建築学科4年生の下川勝広君, 平田直也君. 津田協典君, 藤石健友君, 3年生の小林正純君, 防衛大 学校建設工学科4年生の鈴木若菜さん, 同修士課程の文聖仁君, 許松 君，塚本昭博君，そして建物模型の作成に協力頂いた竹中工務店の寺 島芳洋氏に謝意を表します。

\section{参考文献}

1) 東日本大震災合同調査報告書編集委員会 : 東日本大震災合同調査報告 建 築編5，津波の特性と被害，日本建築学会，pp.101-278，2015.3

2) 濱本卓司：対津波設計か耐津波設計か，日本建築学会大会（関東）構造部 門パネルディスカッション「建築物の津波荷重に関する新たな研究の方向 性を探る」資料, pp.8-17, 2015.9

3) 平成23年国土交通省告示第1318号, 津波浸水想定を設定する際に想定した 津波に対して安全な構造方法等を定める条件, 2011.

4) 中埜良昭ほか：特集「津波避難ビル等の構造設計法等に関する検討」，建 築防災, pp.2-28, 2012.5

5) 日本建築学会：建築物荷重指針・同解説（2015），第11章 津波荷重，日 本建築学会, pp.563-592, 2015.2

6) 日本建築学会 : 建築物荷重指針を活尀設計資料1, 第7章 津波荷重, 日 本建築学会, pp.359-444, 2016.2

7) 日本建築学会: 建築の原点に立ち返る〜暮らしの場の再生と革新 東日本 大震災に鑑みて (第二次提言)，建築雑誌，Vol.128, No.1650, pp.52-65, 2013.10

8) Fujima, K., Achmad, F., Shigihara, Y., M izutani, N.: Estimation of Tsunami Force Acting on Rectangular Structures, J ournal of Disaster Research, Vol.4, N 0.6, pp.404-409, 2009

9) 濱田政則他：耐津波学 津波に強い社会を創る，森北出版，p.209，2015

10) Hirt, C.W., Nicholas, B.D.: V olume of Fluid (VOF) M ethod for the Dynamics of Free Boundaries, J ournal of Computational Physics, V ol.39, pp.201-225, 1981 


\title{
TSUNAMI WATER TANK EXPERIMENT ON LOW-TO-MID-RISE BUILDINGS WITH OPENINGS AND PILOTI SPACE
}

\author{
Takuji HAMAMOTO ${ }^{* 1}$, Yoshinori SHIGIHARA*2, Harumi YASHIRO*3 \\ and Shusaku INOUE*4 \\ ${ }^{* 1}$ Emeritus Prof., Tokyo City University, Dr.Eng. \\ *2 Lect., National Defense Academy, Dr.Eng. \\ ${ }^{*}$ Prof., National Defense Academy, Dr.Eng. \\ *4 Takenaka Corporation, Dr.Eng.
}

A series of tsunami water tank experiments have been conducted to study global and local tsunami actions on low-to-mid-rise buildings with or without openings and piloti space. Each small-scaled experimental model produced by $3 \mathrm{D}$ printer is assumed as a three-story building of square plan with four corner columns and a center core. Wave pressures generated on several portions of external and internal walls are measured to discuss the local tsunami action, whereas wave forces acting on the whole building are measured to discuss the global tsunami action. Numerical analyses have been carried out to simulate the flow of tsunami inside and outside of the buildings and its effect on building structures through the comparison with experimental results.

Based on experimental and analytical results, conclusions within this study are summarized as follows:

1) The existence of piloti space reduces the rise of water level and run-up on the front wall.

2) Breaking of glass windows causes the decrease in wave pressure on the external wall and the increase in wave pressure on the internal core wall.

3) Non-fragile windows cause the increase in water level and run-up at the front surface and consequently the rise of water pressure.

4) Maximum wave pressure tends to be generated on the internal core wall rather than on the external wall.

5) Tsunami flowing into the inside of building drains out of side and rear walls depending on flow velocity.

6) Horizontal wave force acting on the whole building decreases by 20 to $35 \%$ in the case with openings and piloti space compared to the case without openings and piloti space.

7) The core wall should be taken into consideration as a part of projected area in addition to exterior walls to evaluate horizontal wave force.

8) Vertical force acts downwardly in the case with openings and piloti space, although it acts upwardly in the case without openings and piloti space.

9) Tsunami simulation analysis based on VOF method is effective to evaluate both local wave pressure and global wave force.

10) The spatial distribution and time variation of wave pressure acting on the building and flow velocity inside and outside of the building can be accurately evaluated by tsunami simulation analysis.

11) Vertical force can be reasonably evaluated by slightly floating the building portion from the water bed in the analytical model. 